\title{
Differences and similarities in the phenomenon of NETs formation in oral inflammation and in oral squamous cell carcinoma
}

\author{
Marzena Garley ${ }^{1 凶}$, Dorota Dziemiańczyk-Pakieła², Kamil Grubczak³, Arkadiusz Surażyński ${ }^{4}$, Dorota \\ Dąbrowska ${ }^{1}$, Wioletta Ratajczak-Wrona ${ }^{1}$, Jolanta Sawicka-Powierza ${ }^{5}$, Jan Borys², Marcin Moniuszko ${ }^{3}$, Jerzy \\ A. Pałka4, Ewa Jabłońska ${ }^{1}$ \\ 1. Department of Immunology, Medical University of Bialystok, J. Waszyngtona 15A, 15-269 Białystok, Poland; \\ 2. Department of Maxillofacial and Plastic Surgery, Medical University of Bialystok, M. Skłodowskiej-Curie 24A, 15-276 Białystok, Poland; \\ 3. Department of Regenerative Medicine and Immunoregulation, Medical University of Bialystok, J. Waszyngtona 13, 15-269 Białystok, Poland; \\ 4. Department of Medicinal Chemistry, Medical University of Bialystok, A. Mickiewicza 2D, 15-222 Białystok, Poland; \\ 5. Department of Health Sciences, Medical University of Bialystok, Mieszka I 4B, 15-054 Białystok, Poland \\ $\square$ Corresponding author: Marzena Garley, PhD, Department of Immunology, Medical University of Bialystok, Waszyngtona 15A, 15-269 Białystok, Poland; tel.: \\ +48 85 7450547, fax: +48 85 7450588, e-mail: marzena.garley@umb.edu.pl \\ ( $)$ Ivyspring International Publisher. This is an open access article distributed under the terms of the Creative Commons Attribution (CC BY-NC) license \\ (https://creativecommons.org/licenses/by-nc/4.0/). See http://ivyspring.com/terms for full terms and conditions.
}

Received: 2017.12.07; Accepted: 2018.02.17; Published: 2018.04.30

\begin{abstract}
Taking into account the previously reported relationship between inflammation and carcinogenesis, and the scant amount of data concerning the role of neutrophil extracellular traps (NETs) in carcinogenesis, we decided to study the process of extracellular trap formation in patients with inflammation as well as in patients with cancer occurring in the same location. For preliminary isolation of neutrophils (PMNs), we used Polymorphprep ${ }^{\mathrm{TM}}$, then sorted with Microbeads. The cells were recorded in the incubation chamber with a BD Pathway 855 microscope system. Flow cytometric data (MPO+ neutrophils) were acquired on FACSCalibur flow cytometer. Amounts of cfDNA were determined by Abcam's Circulating DNA Quantification Kit. Neutrophils of patients with inflammation and of subjects with stage I/II oral squamous cell carcinoma (OSCC) produce increased amounts of NETs, while stage III/IV OSCC were comparable with the control group. In all of the studied groups of cells stimulation with LPS and rhIL-17 produced more NETs in relation to unstimulated cells. Neutrophil supernatant of inflammation patients and stage I/II cancer patients demonstrated the increased level of cfDNA, which decreased at stage III/IV. Patients with oral inflammations showed an increased rate of MPO+ neutrophils, which was lower than in stage I/II cancer patients and not significantly different than in Stage III/IV cancer patients and the control group. The direction of changes in NETs formation seems to be a new common element shared by inflammation and early stage cancer. Changes in the formation of NETs observed in patients with advanced cancer, other than an early phase or inflammation, indicate an alternative range of NETs involvement depending on different phases of this disease.
\end{abstract}

Key words: cancer; inflammation; neutrophil extracellular traps (NETs); neutrophils (PMNs); oral squamous cell carcinoma (OSCC)

\section{Introduction}

Neutrophil extracellular traps (NETs) are an important component of innate immune response. NETs contain smooth stretches of DNA fibres, which compose most of the trap, numerous granule proteins such as myeloperoxidase or histone proteins. The main function of neutrophil extracellular traps is binding microorganisms to prevent their spread and providing high local concentration of anti-pathogenic agents. Initial reports on NETs indicated their positive role in in vivo infections and confirmed the critical role 
of neutrophils in identifying and destroying invasive pathogens [1]. Numerous studies showed that NETs bind a wide range of Gram-positive and Gramnegative bacteria, fungi, as well as protozoa [2-4].

Recent publications have also highlighted negative effects of NETs on the human body [5, 6]. Many reports suggested that neutrophils are involved in the pathogenesis of disorders with an aggravated inflammatory process, which was initially associated with the cells themselves, but now is ascribed to NETs. It was also pointed out that they may induce autoimmune processes due to prolonged inflammation resulting from the formation of NETs [7-9]. The great example is deimination of histone arginines which can lead to the creation neoantigens trigger for autoimmunity [10]. Increased release of NETs has been demonstrated in vasculitis, systemic lupus erythematosus, rheumatoid arthritis or Crohn's disease, ulcerative colitis and metabolic diseases [11, 12].

Forming NETs neutrophils started to be recognized as important players in infectious as well as noninfectious diseases based on immune system failure, including malignancy $[13,14]$. There is an abundance of data confirming the close relationship between inflammation and cancer [15, 16]. Inflammation mediators and effector cells were found to be crucial in the promotion and progression of the neoplastic process and metastasis. On the other hand, inflammation elements in tumour microenvironment may play a key role in inhibiting the neoplastic process by stimulating the anti-tumour immune mechanisms $[17,18]$.

The researchers who discovered NETs also conducted the first studies to indicate that NETs are likely to be directly involved in a neoplastic disease. These authors demonstrated that tumour associated neutrophils (TANs) are capable of forming extracellular traps in Ewing's sarcoma patients. The presence of TANs and NETs was only detected in patients with metastasis, while in cases of complete remission following intense chemotherapy cancer relapse was fast [19]. Significant amounts of neutrophil extracellular trap structures were found in lung cancer tissues and tissues from patients suffering from osteosarcoma. In experimental models of breast cancer non-small-cell lung carcinoma and chronic myeloid leukaemia neutrophils also indicated higher capacity to form and release NETs [20, 21]. Boone et al. also demonstrated high expression of NETs markers in pancreatic ductal adenocarcinoma and conclude that traps are upregulated through autophagy dependent pathway [22].

Reports on the biological aspect of NETs in the course of cancer are still rather scarce, with opinions on their involvement quite divided. It is speculated that the anti-cancer properties of NETs are connected with direct killing of cancer cells and/or stimulation of other cells in the immune system. On the other hand, extracellular trap components may have a pro-tumour effect in relation to the facilitation of metastasis. Taking into account the well-documented significance of NETs in inflammation and the scant amount of data concerning the role of neutrophil extracellular traps in carcinogenesis, we decided to study the process of extracellular trap formation in patients with inflammation as well as in patients with cancer occurring in the same location. We aimed to evaluate the formation of NETs in patients with oral inflammation and patients with oral squamous cell carcinoma (OSCC). We sought to determine whether the formation of NETs occurs in the same extent in the inflammatory and cancerous process. Detection of differences in the phenomenon of forming NETs in the inflammation and in the cancer process may lead to increased knowledge about the role of the traps in the pathomechanism of these diseases.

\section{Materials and Methods}

\section{Participants}

The study involved a group of 10 patients with odontogenic infection/inflammation, 17 patients with oral squamous cell carcinoma, hospitalized in the Department of Maxillofacial and Plastic Surgery, Medical University of Bialystok, and a group of 15 healthy people, volunteer blood donors. Assays were performed in patients before the treatment. Study results were analyzed taking into account a clinical stage of the disease according to TNM classification. The clinical data of patients and healthy persons is presented in Table 1 (sex, age, WBC, site of inflammation/tumor, stage of disease). Patients with squamous cell carcinoma of the oral mucosa report to the doctor in the late - inoperable stage of the disease, therefore the number of patients collected for the study is not large, but the results obtained in the examined groups were repeatable.

Approved by the Bioethics Committee of the Medical University of Bialystok no. R-I-002/479/2014 and no. R-I-002/59/2016.

\section{Cell isolation}

Upon the donor's consent, blood samples were extracted from the basilic vein and preserved with EDTA for cell isolation, in an amount $9 \mathrm{~mL}$. Preliminary isolation of cells with Polymorphprep ${ }^{\mathrm{TM}}$ (Axis-Shield PoC AS) allows obtaining two well separated leukocyte fractions: polynuclear and mononuclear cells. In order to obtain highest cell purity, polynuclear fraction was then sorted by positive 
selection with Microbeads, which allows for a $100 \%$ cell purity. The neutrophils were sorted using a magnetic MACS® Separator with CD16 Microbeads (for polymorphonuclear cells - PMNs, Miltenyi Biotec).

\section{Cell incubation}

The polymorphonuclear cells were suspended in a culture medium containing RPMI Medium 1640 (Gibco ${ }^{\circledR}$, Life Technologies ${ }^{\mathrm{TM}}$ ), $<5 \%$ calf serum FBS Good (PAN Biotech), antibiotic Penicillin-Streptomycin (Sigma Life Science) in an amount of $10^{5}$ per well for NETs visualization and $5 \times 10^{5}$ for flow cytometry method.

Then, the cells were incubated 1 hour in microplatelets (Microtest III-Falcon, BD Biosciences) at $37^{\circ} \mathrm{C}$, in an incubator with a flow of $5 \% \mathrm{CO}_{2}$.

Neutrophils were incubated in the presence of rhIL-17 at a concentration of $50 \mathrm{ng} / \mathrm{mL}$ (Bender Med System) or LPS - $10 \mu \mathrm{g} / \mathrm{mL}$ (Sigma-Aldrich, Merck).

\section{Cell purity assessment}

Collected cell suspensions purity was assessed with a "thick-drop" preparation, using MayGrünewald-Giemsa staining (AquaMed). The purity of all of the cell suspensions was $>99.6 \%$.

\section{Cell viability assessment}

The viability of the cells was assessed immediately after separation in a light microscope using trypan blue (Lachema). The viability of PMNs after isolation were $>97 \%$ of all of the tested cells.

\section{BD Pathway 855 microscopic system}

The incubation of stimulated cells at $37^{\circ} \mathrm{C}$, in an incubator with a flow of $5 \% \mathrm{CO}_{2}$, was recorded in the incubation chamber with a BD Pathway 855 microscope system. The analysis involved NETs structures: DNA (Hoechst 33342, Invitrogen ${ }^{\mathrm{TM}}$ ) and myeloperoxidase (MPO; clone 8E6, Molecular Probes ${ }^{\circledR}$, Life Technologies ${ }^{\mathrm{TM}}$ ).

\section{Flow cytometry}

Following 1 hour incubation neutrophils were permeabilized using FACS Permeabilizng Solution 2 (BD Biosciences) and stained with anti-Human Myeloperoxidase monoclonal antibodies (clone 8E6, Molecular Probes ${ }^{\circledR}$, Life Technologies $\left.{ }^{\mathrm{TM}}\right)$. Flow cytometric data were acquired on FACSCalibur flow cytometer (BD Biosciences) and analysed with the use of FlowJo software (Tristar Inc., Ashland, OR, USA). Neutrophils were gated on the basis of forward scatter (FSC) and side scatter (SSC) properties, and the frequency of myeloperoxidase-positive cells was presented as frequency of total neutrophils.

\section{Circulating DNA Quantification Kit}

Amounts of circulating DNA in blood serum and cell supernatants were determined by Abcam's Circulating DNA Quantification Kit according to the instructions enclosed. DNA was fluorescently quantified.

Table 1. The clinical data of patients and healthy persons.

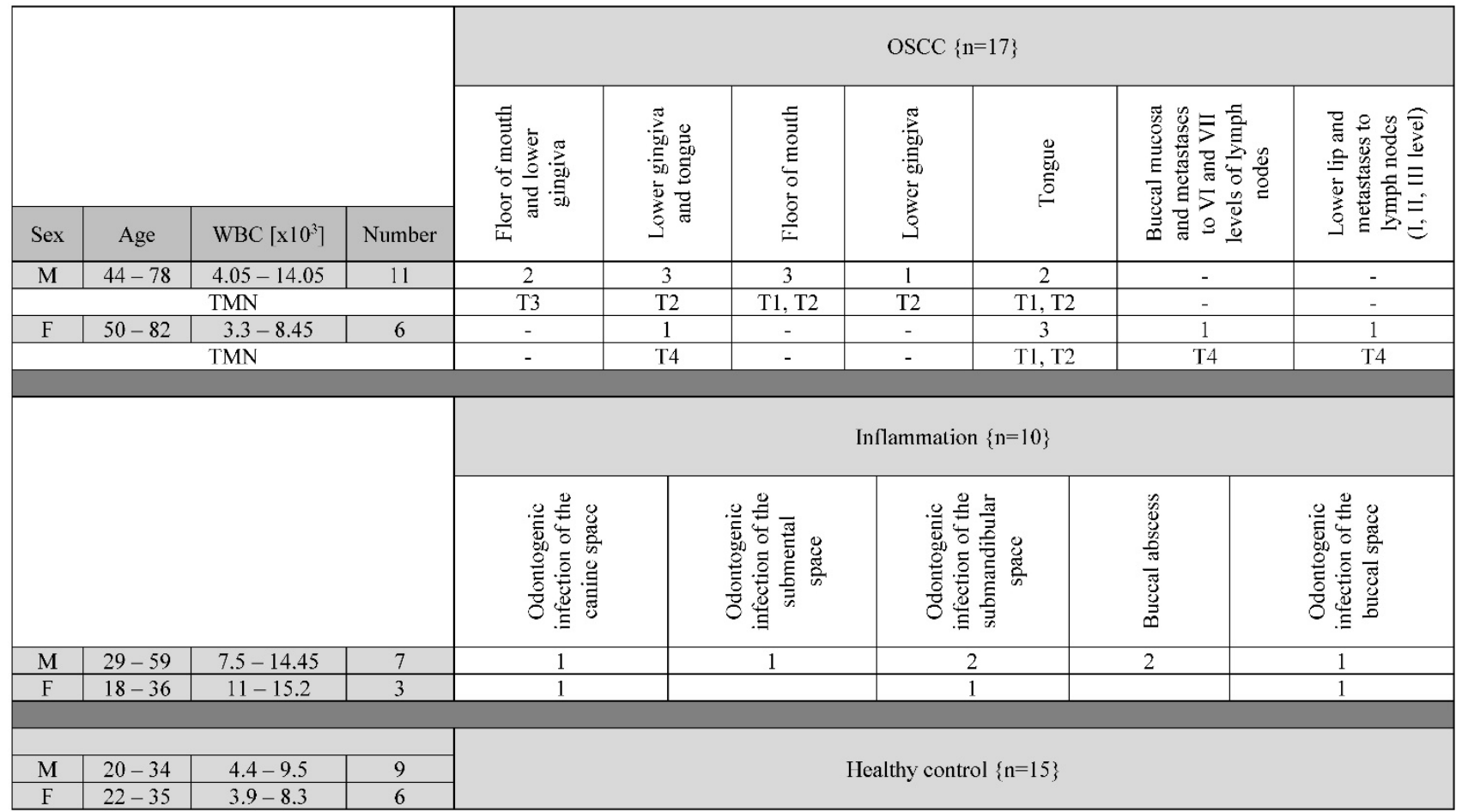

The table presents the basic clinical data of the study participants. Abbreviation: WBC - white blood cells (amount); OSCC - oral squamous cell carcinoma; TNM classification of clinical stage of the disease; $\mathrm{M}$ - male; $\mathrm{F}$ - female. 


\section{Statistical analysis}

Statistical analysis used the Microsoft Excel calculation sheet and STATISTICA version 13.1. Data distribution normality was determined using Kolmogorov-Smirnov test. Since the data were not normally distributed, for comparison of variation between assayed groups, Mann-Whitney U non-parametric tests were applied to un-related results. The correlation between variables was evaluated using Spearman's rank coefficient (r). A $p$ value $\leq 0.05$ was accepted as statistically significant. All data are presented as mean \pm SEM (standard error of the mean).

\section{Results}

\section{Microscope evaluation of NET formation}

Microscopy results indicate that neutrophils of patients with inflammation in the oral cavity and of subjects with stage I/II cancer produce increased amounts of NETs compared to cells of healthy subjects. No significant differences in the release of NETs were observed between the neutrophils of these groups of patients. However, the amount of unstimulated neutrophils releasing NETs in stage III/IV cancer patients was comparable to that of healthy subjects and lower than the amount of neutrophils in inflammation and early stage cancer

patients (Table 2, Fig. 1).

In all of the studied groups neutrophils after stimulation with LPS and rhIL-17 produced more NETs in relation to unstimulated cells. Patients with inflammation and early stage cancer showed elevated formation of NETs after stimulation with LPS than rhIL-17. NET formation in stimulated cells of stage III/IV cancer patients was observed to be highest after incubation of the cells in the presence of rhIL-17. LPS-stimulated neutrophils in these patients, on the other hand, released less NETs in comparison to healthy cells (Table 2, Fig. 1).

Table 2. The percentage of neutrophils forming NETs.

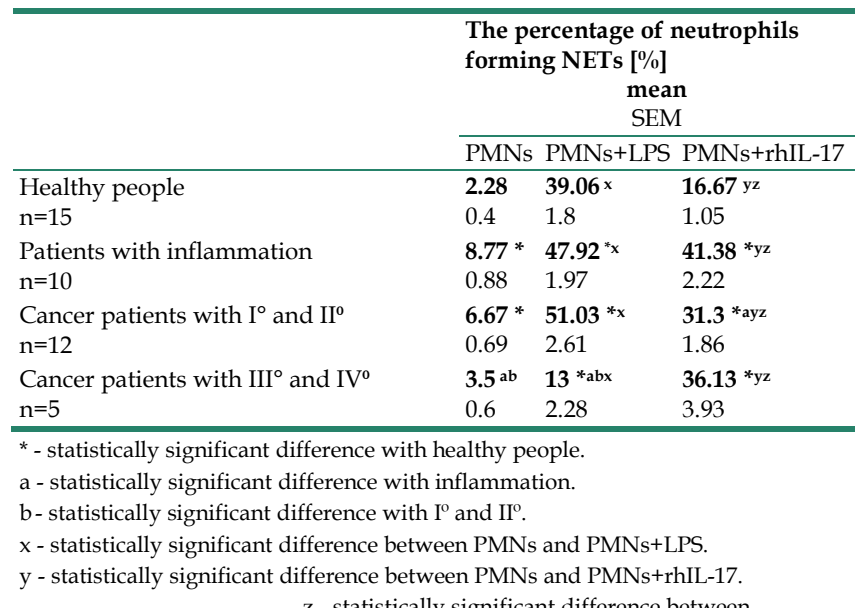
$\mathrm{z}$ - statistically significant difference between
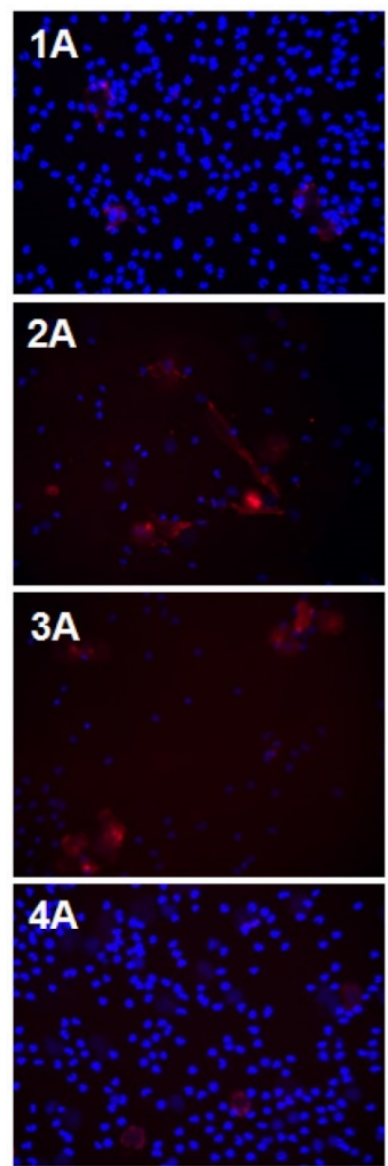
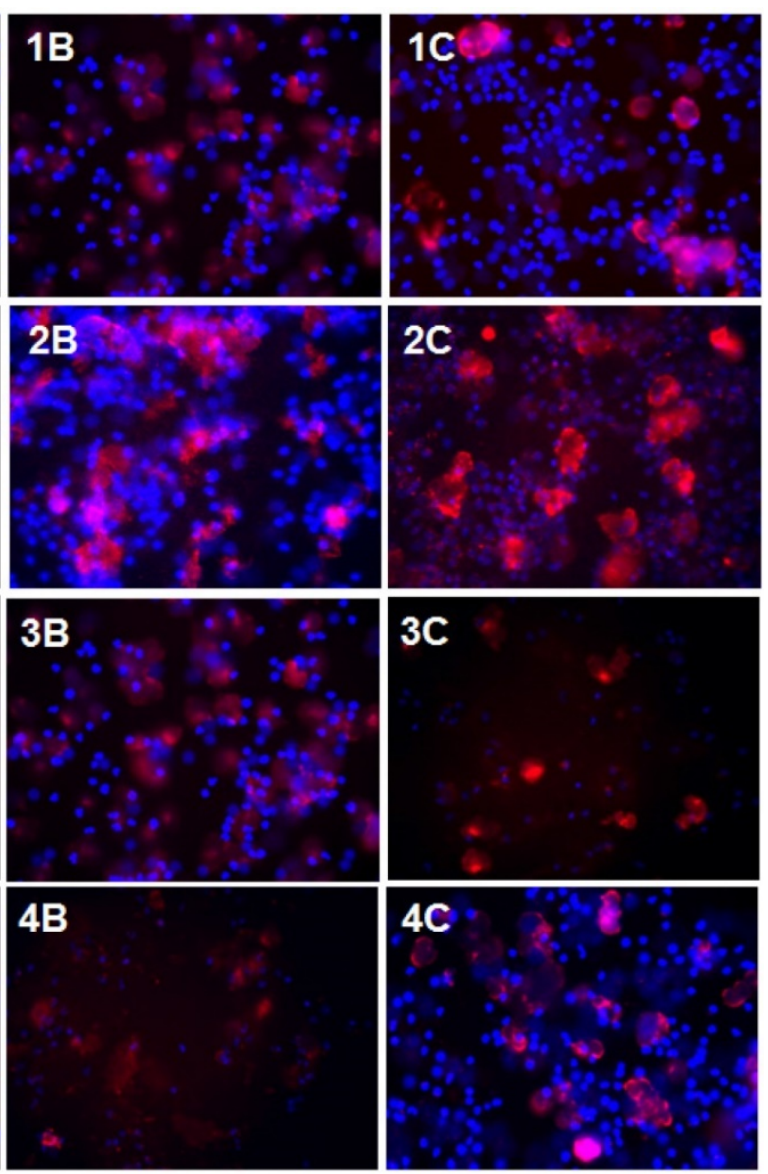
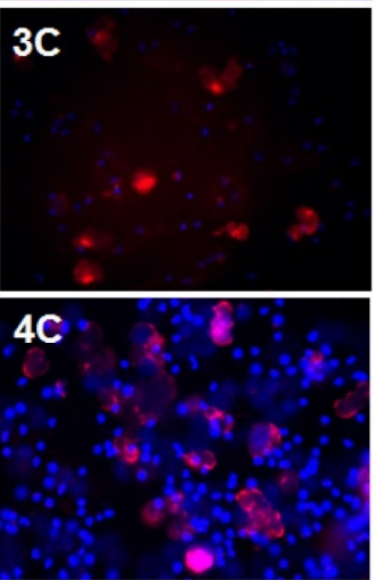

Figure 1. NETs in confocal microscopy. The figure presents sample photos of neutrophil culture without and with LPS or rhlL-17 stimulation in patients and healthy persons, after 60 minutes incubation, with 20x zoom. Staining of total DNA blue color, staining of extracellular MPO - red color. Abbreviation: A - unstimulated, B - LPS stimulation, C - IL-17 stimulation; 1 - control, 2 - inflammation, 3 $-I^{\circ} / I^{\circ}, 4-I^{\circ} / \mathrm{IV}^{\circ}$. 
Fluorescent assay of cfDNA in cell supernatant and blood plasma

Assay of neutrophil supernatant of inflammation patients and stimulated neutrophils in stage I/II cancer patients found increased levels of cfDNA compared to healthy subjects. On the other hand, the cell supernatants of patients with stage III/IV cancer showed significantly lower concentration of cfDNA in comparison to healthy subjects, patients with inflammation and patients in early-stage cancer (Table 3).

Table 3. The cfDNA concentration in supernatants and serum.

\begin{tabular}{|c|c|c|c|c|}
\hline & \multicolumn{4}{|c|}{$\begin{array}{c}\text { cfDNA }[\mathrm{ng} / \mu \mathrm{L}] \\
\text { mean } \\
\text { SEM }\end{array}$} \\
\hline & \multirow[t]{2}{*}{ Serum } & \multicolumn{3}{|c|}{ Supernatants } \\
\hline & & PMNs & PMNs+LPS & PMNs+rhIL-17 \\
\hline $\begin{array}{l}\text { Healthy people } \\
n=15\end{array}$ & $\begin{array}{l}95 \\
7.18\end{array}$ & $\begin{array}{l}\mathbf{1 4 7} \\
13.22\end{array}$ & $\begin{array}{l}263^{x} \\
19.57\end{array}$ & $\begin{array}{l}197 \mathrm{yz} \\
11.48\end{array}$ \\
\hline $\begin{array}{l}\text { Patients with } \\
\text { inflammation } \\
\mathrm{n}=10\end{array}$ & $\begin{array}{l}\mathbf{1 5 4 . 5 0} \text { * } \\
34.50\end{array}$ & $\begin{array}{l}346 * \\
30.07\end{array}$ & $\begin{array}{l}\mathbf{5 3 4} * \mathbf{x} \\
50.45\end{array}$ & $\begin{array}{l}519 * y \\
42.23\end{array}$ \\
\hline $\begin{array}{l}\text { Cancer patients with } \mathrm{I}^{\circ} \\
\text { and } \mathrm{II}^{\circ} \\
\mathrm{n}=12\end{array}$ & $\begin{array}{l}182 * \\
12.23\end{array}$ & $\begin{array}{l}204.20 \text { a } \\
28.72\end{array}$ & $\begin{array}{l}639 * x \\
44.51\end{array}$ & $\begin{array}{l}480 * y z \\
33.73\end{array}$ \\
\hline $\begin{array}{l}\text { Cancer patients with } \\
\mathrm{III}^{\circ} \text { and } \mathrm{IV}^{0} \\
\mathrm{n}=5\end{array}$ & $\begin{array}{l}\mathbf{1 4 3 . 7 5 *} \\
16.13\end{array}$ & $\begin{array}{l}32 * a b \\
3.00\end{array}$ & $\begin{array}{l}46.50 * a b \\
2.5\end{array}$ & $\begin{array}{l}110.33 * \text { *abyz } \\
5.78\end{array}$ \\
\hline $\begin{array}{l}\text { * - statistically significant } \\
\text { a - statistically significan } \\
\text { b- statistically significant } \\
\text { x - statistically significan } \\
\text { y - statistically significan } \\
\text { z - statistically significan }\end{array}$ & $\begin{array}{l}\text { difference } \\
t \text { differenc } \\
t \text { difference } \\
t \text { differenc } \\
t \text { differenc } \\
t \text { differenc }\end{array}$ & $\begin{array}{l}\text { ith healthy } \\
\text { ith inflam } \\
\text { ith } \mathrm{I}^{\circ} \text { and I } \\
\text { etween PM } \\
\text { etween PM } \\
\text { tween PM }\end{array}$ & $\begin{array}{l}\text { ople. } \\
\text { ion. } \\
\text { and PMNs+L } \\
\text { and PMNs+r } \\
+ \text { LPS and PM }\end{array}$ & $\begin{array}{l}\text { PS. } \\
\text { AIL-17. } \\
\text { Ns+rhIL-17. }\end{array}$ \\
\hline
\end{tabular}

Stimulation of neutrophils with LPS or nrIL-17 in patients with inflammation or stage I/II cancer increased the cfDNA fraction in the supernatants of these cells, with the highest concentration of cfDNA found in the presence of LPS. Neutrophil supernatants of stage III/IV cancer patients was significantly higher than the concentration showed significant increases of free DNA only in the presence of rhIL-17 (Table 3).

Analysis of cfDNA in blood serum of patients with inflammation and all of the cancer patients showed an increase of free DNA in relation to healthy subjects (Table 3 ).

\section{Cytometric analysis of MPO expression in neutrophils}

Neutrophils of patients with odontogenic infection demonstrated increased percentage of MPO-positive neutrophils (MPO+), both stimulated with rhIL-17 and unstimulated, compared to healthy subjects. LPS stimulation was also found to result in the lowest percentage of $\mathrm{MPO}+$ neutrophils in relation to unstimulated cells (Table 4, Fig. 2).

Stage I/II cancer patients presented the lowest percentage of $\mathrm{MPO}+$ neutrophils in stimulated and unstimulated cells in relation to healthy subjects, inflammation subjects, as well as patients with advanced cancer, apart from neutrophils incubated with rhIL-17. No significant changes were found in the number of $\mathrm{MPO}+$ neutrophils after using stimulants on this group of patients (Table 4, Fig. 2).

The percentage of unstimulated $\mathrm{MPO}+$ neutrophils in stage III/IV cancer patients was similar to that of healthy subjects. The lowest percentage of $\mathrm{MPO}+$ neutrophils in relation to all of the studied groups of cells was observed in stage III/IV cancer patients after incubating the cells in the presence of rhIP-17 (Table 4, Fig. 2).

No statistically significant correlation between the studied parameters was found.

Table 4. The percentage of neutrophils MPO+.

\begin{tabular}{|c|c|c|c|}
\hline & \multicolumn{3}{|c|}{$\begin{array}{c}\text { The percentage of neutrophils MPO+ [\%] } \\
\text { mean } \\
\text { SEM }\end{array}$} \\
\hline & PMNs & PMNs+LPS & PMNs+rhIL-17 \\
\hline $\begin{array}{l}\text { Healthy people } \\
n=15\end{array}$ & $\begin{array}{l}29.4 \\
4.17\end{array}$ & $\begin{array}{l}42.4 \times \\
5.13\end{array}$ & $\begin{array}{l}28 \mathrm{z} \\
2.63\end{array}$ \\
\hline $\begin{array}{l}\text { Patients with inflammation } \\
n=10\end{array}$ & $\begin{array}{l}47.93 * \\
5.28\end{array}$ & $\begin{array}{l}29.63 \times \\
5.47\end{array}$ & $\begin{array}{l}41.95 * \\
2.15\end{array}$ \\
\hline $\begin{array}{l}\text { Cancer patients with } \mathrm{I}^{\circ} \text { and } \mathrm{II}^{\circ} \\
\mathrm{n}=12\end{array}$ & $\begin{array}{l}\mathbf{1 2 . 0 3} * \mathrm{a} \\
1.31\end{array}$ & $\begin{array}{l}\mathbf{1 4 . 4 2} * \mathrm{a} \\
1.25\end{array}$ & $\begin{array}{l}\mathbf{1 1 . 3 8} * \mathrm{a} \\
1.22\end{array}$ \\
\hline $\begin{array}{l}\text { Cancer patients with } \mathrm{III}^{\circ} \text { and } \\
\mathrm{IV}^{0} \\
n=5\end{array}$ & $\begin{array}{l}25.70^{b} \\
9.69\end{array}$ & $\begin{array}{l}32.20^{b} \\
4.90\end{array}$ & $\begin{array}{l}8.42 * a z \\
2.57\end{array}$ \\
\hline $\begin{array}{l}\text { * - statistically significant differer } \\
\text { a - statistically significant differe } \\
\text { b - statistically significant differer } \\
\text { x - statistically significant differe }\end{array}$ & $\begin{array}{l}\text { nce with } \mathrm{h} \\
\text { nce with ir } \\
\text { nce with } \mathrm{I}^{\circ} \\
\text { nce betwe }\end{array}$ & $\begin{array}{l}\text { people. } \\
\text { tation. } \\
\text {. } \\
\text { Ns and PMI }\end{array}$ & s. \\
\hline
\end{tabular}

\section{Discussion}

The results of conducted tests indicate that the formation of NETs is associated not only with inflammatory states, but also with cancers of the oral mucosa. Formation of the traps pertains mainly to early stages of the disease, since no significant changes were observed in patients suffering from advanced cancer. The high intensity of NETs formation in patients with $\mathrm{I} / \mathrm{II}^{\circ}$ stage appears to facilitate the progress of a disease. It is known that the trap structures might promote migration and immune escape of cancer cells or constitute a physical barrier between cancer cells and immune-competent cells. Furthermore, excessive formation of NETs in close vicinity of blood vessel walls may make it easier for neoplastic cells to bind to the endothelium and contribute to extravasation and implicate in the process of cancer metastasis. Additionally, NETs may enhance immune escape by covering circulating cancer cells with blood platelets $[8,23]$. 


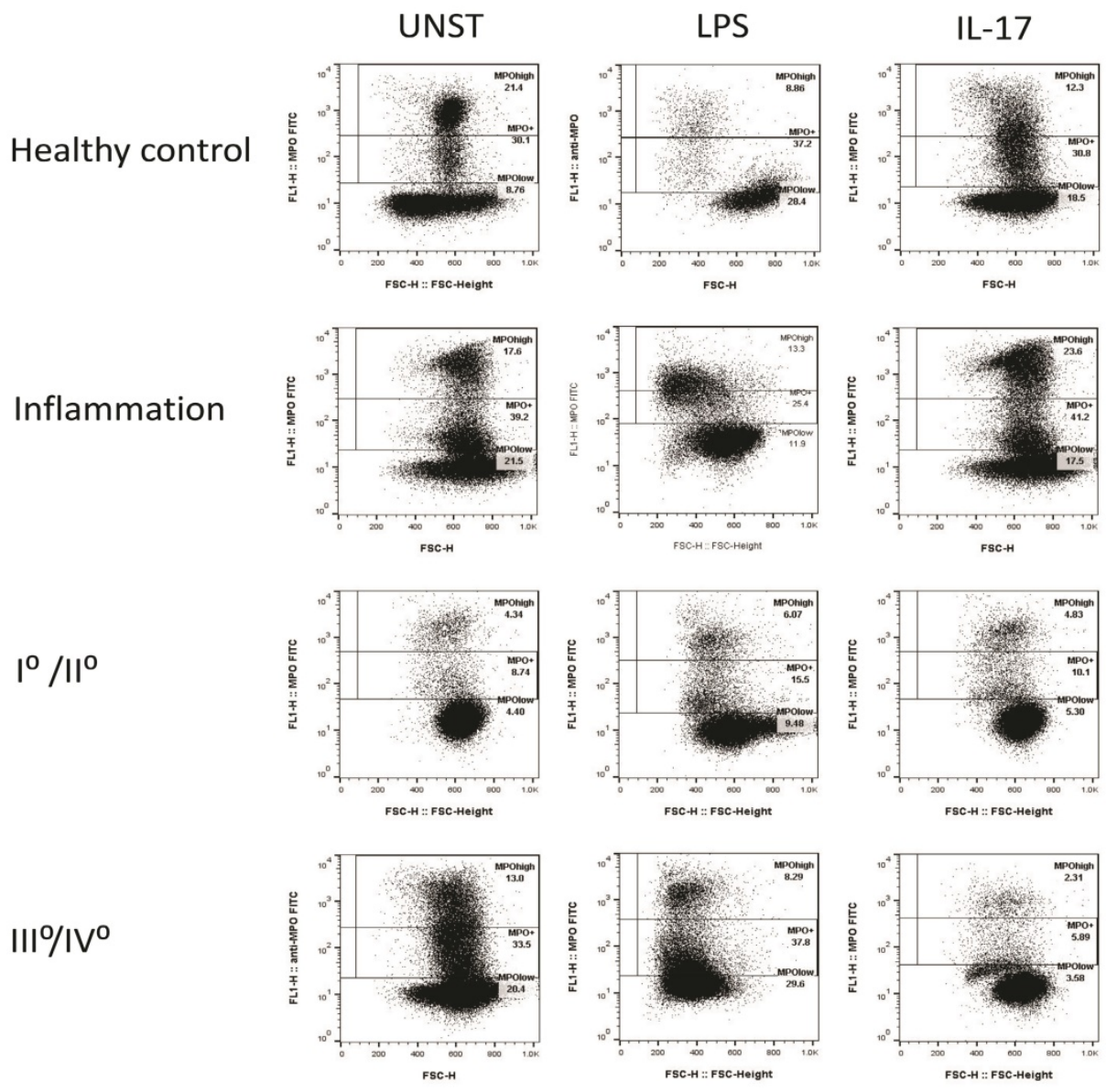

Figure 2. Representative graphs of cytometric analysis of MPO+ neutrophils. The figure shows examples of graphs of cytometric analysis of MPO-positive neutrophils in patients and healthy persons, after 60 minutes neutrophil incubation without and with LPS or rhlL-17. Abbreviation: UNST - unstimulated.

On the other hand, Arelaki et al. observed that the in vitro-generated NETs inhibited growth of colon cancer cells by inducing apoptosis and/or inhibiting proliferation [24].

Taking into consideration, that people with MPO deficiency have a higher risk of a cancer incident we examined a population of MPO+ neutrophils $[25,26]$. In the early stage of the disease, when the formation of NETs is increased, a low percentage of $\mathrm{MPO}+$ neutrophils was observed. This observation suggests increasing extracellular MPO content and seems to be beneficial because research conducted by Odajima et al. indicate that MPO is directly involved in killing cancer cells, as shown in tests on melanoma cells. It was also shown that the myeloperoxidase inhibits the growth of these cells after implantation [27]. In contrast, the lack of changes in NETs formation with an increased amount of MPO+ neutrophils in patients with advanced cancer seems advantageous. Our research also showed that increased amounts of released NETs in inflammation patients was accompanied by raised levels of MPO+ neutrophils, which may suggest further neutrophil mobilization for NETs formation.
We have shown that increased formation of NETs in early stage cancer and inflammation is accompanied by higher amounts of cfDNA in neutrophil supernatants and plasma, which clearly indicates that PMNs are a significant source of circulating free DNA. The increase of free DNA in blood plasma of cancer patients was reported in numerous articles preceding the discovery of NETs $[28,29]$. At the time it was believed that the cfDNA came from fragmented/destroyed cancer cells [30]. The decreased amount of cfDNA in the blood plasma of stage III/IV cancer patients observed in our own research may result from binding of NETs fragments with the large amount of circulating cancer cells.

The adverse role of NETs in the course of cancer could stem from the fact that these structures provide a scaffold for thrombus, and the stimulation of adhesion of platelets only contributes to the phenomenon $[19,20]$. At later stages of the disease when the level of DNA was detectable in blood plasma, the subjects presented spontaneous thrombosis, and the amount of NETs was correlated with the signs of thrombosis [31].

Not only thrombosis but also pneumonia, 
peritonitis, and sepsis are strongly related to the increase of deaths resulting from metastasis, as shown in numerous forms of cancer [32, 33]. Our research suggests that LPS is significant in inducing the formation of NETs in early stages of cancer. This is also confirmed by Demers et al., who found that administering small doses of LPS to mice with cancer was correlated with high levels of NETs biomarkers in blood plasma [20]. Cools-Latigue et al. conducted research on mice which showed that the formation of NETs after stimulation with LPS correlates with a 50\% increase of lung cancer cell adhesion in the liver, the most frequent metastasis site. These discoveries incorporate NETs into the pathomechanism of tumour metastasis in the context of bacteria-related inflammation [34]. It is interesting why there is a slight decrease in the number of MPO+ neutrophils after stimulation with LPS both in inflammation and cancer patients. This is probably the result of a loss of $\mathrm{MPO}+$ cells associated with NETs formation, as observed in the inverse relationship between the amount of cfDNA in the PMNs supernatant and the number of MPO+ neutrophils after stimulation of cells of inflammation patients with LPS. However, there is data indicates that metastatic breast cancer cells can induce NETs in the absence of infection. Using intravital imaging in mice, Park et al. observed NETs structures around metastatic cancer cells that had reached the lungs [35]. Authors of experiments conducted in patients undergoing attempted curative liver resection for metastatic colorectal cancer, that increased postoperative NETs formation was associated with a more than 4 -fold reduction in disease-free survival. In a murine model of surgical stress employing liver ischemia-reperfusion, they observed that NETs formation was correlated with an accelerated development and progression of metastatic disease [36].

Neutrophils are called "sophisticated immune cells" because, among others, they can release immunomodulatory cytokines, including IL-17 [11]. The IL-17 family seems to play an important role in the inflammatory and cancerous process. The available data suggests that IL-17 has a double-sided function, similarly to NETs. On the one hand, IL-17 stimulates the function of cytotoxic $\mathrm{T}$ lymphocytes, leading to the regression of cancer. On the other hand, it could also contribute to the progression of cancer by facilitating angiogenesis and escape of cancer cells [37, 38]. Previously conducted research found increased concentration of IL-17 not only in the plasma of inflammation patients, but also in patients with squamous cell carcinoma of the oral mucosa [39]. Presented in this manuscript our own research showed that IL-17 is capable of stimulating NETs formation by neutrophils of healthy subjects, inflammation patients, and cancer patients, as confirmed by the increase of cfDNA in the supernatants of the stimulated cells. It is interesting to note, that the formation of NETs observed in response to IL-17 is stronger than in response to LPS in patients with advanced cancer.

Studying the mechanism of the formation and regulation of neutrophil extracellular traps could have a large impact on understanding the role of the innate immune response in the course of cancer. The same direction of changes in NETs formation seems to be a new common element shared by inflammation and early stage cancer. Changes in the formation of NETs observed in patients with advanced cancer, other than an early phase or inflammation, indicate an alternative range of NETs involvement depending on different phases of this disease. Future research on the formation of neutrophil extracellular traps extending to other biomarkers of NETs may contribute to better understanding the role of these structures in the course of cancer.

\section{Acknowledgements}

This study was conducted with the use of equipment purchased by Medical University of Bialystok as part of the RPOWP 2007-2013 funding, Priority I, Axis 1.1, contract No. UDA- RPPD.01.01.0020-001/15-00 dated 26.06.2015.

\section{Competing Interests}

The authors have declared that no competing interest exists.

\section{References}

1. Brinkmann V, Reichard U, Goosmann C, Fauler B, Uhlemann Y, et al. Neutrophil extracellular traps kill bacteria. Science. 2004; 303: 1532-1535.

2. Abi Abdallah D, Lin C, Ball C, King M, Duhamel G, et al. Toxoplasma gondii triggers release of human and mouse neutrophil extracellular traps. Infect Immun. 2012; 80: 768-777.

3. Bianchi M, Niemiec MJ, Siler U, Urban CF, Reichenbach J. Restoration of anti-Aspergillus defense by neutrophil extracellular traps in human chronic granulomatous disease after gene therapy is calprotectin-dependent. J Allergy Clin Immunol. 2011; 127: 1243-1252.

4. Döring P, Grumann D, Kolata J, Goosmann C, Löffler B, et al. Neutrophil cell death induction by Staphylococcus aureus from nasal colonization and chronic furunculosis. Int J Med Microbiol. 2011; 301:40.

5. Garley M, Jabłońska E, Ratajczak-Wrona W. Role of NETs, positive or negative? Postepy Biol Kom. 2013; 40: 307-320.

6. Lögters T, Margraf S, Altrichter J, Cinatl J, Mitzner S, et al. The clinical value of neutrophil extracellular traps. Med Microbiol Immunol. 2009; 198: 211-219.

7. Hakkim A, Fürnrohr BG, Amann K, Laube B, Abed U, et al. Impairment of neutrophil extracellular trap degradation is associated with lupus nephritis. Proc Natl Acad Sci U S A. 2010; 107: 9813-9818.

8. Fuchs TA, Brill A, Duerschmied D, Schatzberg D, Monestier M, et al. Extracellular DNA traps promote thrombosis. PNAS. 2010; 107: 15880-15885.

9. Pruchniak MP, Kotuła I, Manda-Handzlik A. Neutrophil extracellular traps (Nets) impact upon autoimmune disorders. Centr Eur J Immunol. 2015; 40: 217-224.

10. Sørensen OE, Borregaard N. Neutrophil extracellular traps - the dark side of neutrophils. J Clin Invest. 2016; 126: 1612-1620.

11. Delgado-Rizo V, Martínez-Guzmán MA, Iñiguez-Gutierrez L, García-Orozco A, Alvarado-Navarro A, et al. Neutrophil extracellular traps and its implications in inflammation: an overview. Front Immunol. 2017; 8: 81 
12. Yang H, Biermann MH, Brauner JM, Liu Y, Zhao Y, et al. New insights into neutrophil extracellular traps: mechanisms of formation and role in inflammation. Front Immunol. 2016; 7: 302.

13. Manda A, Pruchniak MP, Araźna M, Demkow UA. Neutrophil extracellular traps in physiology and pathology. Cent Eur J Immunol. 2014; 39: 116-121.

14. Arazna M, Pruchniak MP, Zycinska K, Demkow U. Neutrophil extracellular trap in human diseases. Adv Exp Med Biol. 2013; 756: 1-8.

15. Mantovani A, Allavena P, Sica A, Balkwill F. Cancer-related inflammation. Nature. 2008; 454: 436-444.

16. Rakoff-Nahoum S. Why cancer and inflammation? Yale J Biol Med. 2006; 79: 123-130.

17. Zamarron BF, Chen W. Dual roles of immune cells and their factors in cancer development and progression. Int J Biol Sci. 2011; 7: 651-658.

18. Whiteside TL. The tumor microenvironment and its role in promoting tumor growth. Oncogene. 2008; 100: 203-229.

19. Berger-Achituv S, Brinkmann V, Abed UA, Kühn LI, Ben-Ezra J, et al. A proposed role for neutrophil extracellular traps in cancer immunoediting. Front Immunol. 2013; 4: 48

20. Demers M, Krause DS, Schatzberg D, Martinod K, Voorhees JR, et al. Cancers predispose neutrophils to release extracellular DNA traps that contribute to cancer-associated thrombosis. PNAS. 2012; 109: 13076-13081.

21. Cools-Lartigue J, Spicer J, Najmeh S, Ferri L. Neutrophil extracellular traps in cancer progression. Cell Mol Life Sci. 2014; 71: 4179-4194.

22. Boone BA, Orlichenko L, Schapiro NE, Loughran P, Gianfrate GC, et al. The receptor for advanced glycation and products (RAGE) enhances autophagy and neutrophil extracellular traps in pancreatic cancer. Cancer Gene Ther. 2015; 22: 326-334.

23. Cools-Lartigue J, Spicer J, Mcdonald B, Gowing S, Chow S, et al. Neutrophil extracellular traps sequester circulating tumor cells and promote metastasis. J Clin Invest. 2013; 67484.

24. Arelaki S, Arampatzioglou A, Kambas K, Papagoras C, Miltiades P, et al. Gradient infiltration of neutrophil extracellular traps in colon cancer and evidence for their involvement in tumour growth. PLoS One. 2016; 11: e0154484.

25. Metzler KD, Fuchs TA, Nauseef WM, Reumaux D, Roesler J, et al Myeloperoxidase is required for neutrophil extracellular trap formation: implications for innate immunity. Blood. 2011; 117: 953-959.

26. Al-Benna S, Shai Y, Jacobsen F, Steinstraesser L. Oncolytic activities of host defense peptides. Int J Mol Sci. 2011; 12:8027-8051.

27. Odajima T, Onishi M, Hayama E, Motoji N, Momose Y, et al. Cytolysis of B-16 melanoma tumor cells mediated by the myeloperoxidase and lactoperoxidase systems. Biol Chem. 1996; 377:689-693.

28. Ramirez JL, Taron M, Balaña C, Sarries C, Mendez P, et al. Serum DNA as a tool for cancer patient management. Rocz Akad Med Bialymst. 2003; 48: 34-41.

29. Chan AK, Chiu RW, Lo YM. Clinical Sciences Reviews Committee of the Association of Clinical Biochemists. Cell-free nucleic acids in plasma, serum and urine: a new tool in molecular diagnosis. Ann Clin Biochem. 2003; 40: 122-130.

30. Ziegler A, Zangemeister-Wittke U, Stahel RA. Circulating DNA: a new diagnostic gold mine? Cancer Treat Rev 2002; 28: 255-271.

31. Demers M, Wagner DD. Neutrophil extracellular traps a new link to cancer-associated thrombosis and potential implications for tumor progression. Oncoimmunology. 2013; 2(2):22946-22949.

32. Van Den Berg YW, Reitsma PH. Not exclusively tissue factor: neutrophil extracellular traps provide another link between chemotherapy and thrombosis. J Thromb Haemost. 2011; 9: 2311-2312.

33. Tsou CC, Lo SS, Fang WL, Wu CW, Chen JH, et al. Risk factors and management of anastomotic leakage after radical gastrectomy for gastric cancer. Hepatogastroenterology. 2011; 58: 218-223.

34. Cools-Lartigue J, Spicer J, Mcdonald B, Chow S, Kubes P, et al. Neutrophil extracellular traps sequester circulating tumor cells in vitro and in a murine model of metastasis. Cancer Res. 2012; 72 (8 Suppl): Supplement 1.

35. Park J, Wysocki RW, Amoozgar Z, Maiorino L, Fein MR, et al. Cancer cells induce metastasis-supporting neutrophil extracellular DNA traps. Sci Transl Med. 2016; 8: 361ra138.

36. Tohme S, Yazdani HO, Al-Khafaji AB, Chidi AP, Loughran P, et al. Neutrophil extracellular traps promote the development and progression of liver metastases after surgical stress. Cancer Res. 2016; 76: 1367-1380.

37. Garley M, Jabłońska E, Ratajczak-Wrona W. Interleukin 17 cytokines family in cancer disease. Nowa Medycyna. 2013; 1(s): 21-25.

38. Amatya N, Garg AV, Gaffen SL. IL-17 Signaling: The Yin and the Yang. Trends Immunol. 2017; 38: 310-322.

39. Garley M, Jabłońska E. Chosen IL-17 family proteins in neutrophils of patients with oral inflammation. Adv Med Sci. 2008; 53: 326-330. 